JKM (Jurnal Kebidanan Malahayati),Vol 7,No.2.April 2021,

ISSN (Print) 2476-8944 ISSN (Online) 2579-762X, Hal 295-302

\title{
PENGETAHUAN BERHUBUNGAN DENGAN TINDAKAN IBU HAMIL DALAM MENGKONSUMSI TABLET ZAT BESI
}

\author{
Naili Rahmawati ${ }^{1}$ \\ Sekolah Tinggi Ilmu Kesehatan Dharma Husada Bandung \\ Koresppondensi email nailirahmawati.djati@gmail.com
}

\section{ABSTRACT : KNOWLEDGE RELATING TO PREGNANT WOMEN'S ACTIONS IN EATING IRON TABLETS}

Background: According WHO (World Health Organization), in developing countries there are $40 \%$ of maternal deaths related to anemia during pregnancy. The frequency of pregnant women in Indonesia who experience anemia is still very high, namely $63.5 \%$ compared to only $6 \%$ in America. The number of pregnant women who experience anemia is due to a lack of knowledge of the mother, amounting to $45.6 \%$ of pregnant women do not know the consequences of anemia, do not regularly consume Fe tablets, and do not understand how to consume Fe tablets properly. Knowledge is a very important domain in shaping one's actions. Knowledge is one of the factors to create a person's attitude. Good knowledge about the importance of iron will create a positive attitude towards adherence in consuming iron tablets. Knowledge of the benefits of something can affect the intention to participate in an activity. Knowledge of the benefits and bad consequences of something will create an attitude an intention, then from that attitude an intention will be arisen. The next intention will determine whether the activity will be carried out or not.

Purpose: The objective of this study is to determine the correlation of knowledge and actions of pregnant women in consuming iron tablet at the Midwives Independent Practice ' $\%$ '.

Methods: This research is a quantitative study with cross sectional approach. Data were collected using primary data. The research was conducted in August - September 2019. The population in this study were pregnant women at Praktik Mandiri Midwife I, as a sample. In this study, some of the pregnant women at the Midwife's Independent Practice I. Sampling was carried out using the accidental sumpling technique as many as 30 people. With the inclusion criteria, they can write, read, understand Indonesian and be in good health. Researchers used primary data, namely data obtained by interviewing a questionnaire instrument. Analysis of the data used in this study consisted of two stages of analysis as follows: univariate analysis. Univariate analysis and analysis of research data were carried out using the Spearman test.

Results: The results showed that $97 \%$ of pregnant women had good knowledge, $3 \%$ of pregnant women with less knowledge, and 100\% of pregnant women with positive action in consuming iron tablets. Bivariate analysis using the Spearman test shows that there is a significant relationship between knowledge and actions of pregnant women in consuming iron tablets.

Conclusions: There is a significant correlation conclusion between knowledge and actions of pregnant women in consuming iron tablets. To increase the knowledge and actions of pregnant women in consuming iron tablets is required a counseling routinely and incresed distribution of iron tablet through cross program and cross sectoral activities.

Suggestion to increase the knowledge of pregnant women in consuming iron tablets, it is necessary to conduct regular counseling by midwives in collaboration with the health center.

Keywords: knowledge, actions, pregnant women, iron tablet

\section{ABSTRAK}

Latar Belakang: Menurut WHO (World Health Organization), di negara berkembang terdapat $40 \%$ kematian ibu berkaitan dengan anemia dalam kehamilan. Frekuensi ibu hamil di Indonesia yang mengalami anemia masih sangat tinggi yaitu $63,5 \%$ dibandingkan di Amerika hanya $6 \%$. Banyaknya ibu hamil yang mengalami anemia disebabkan karena kurangnya pengetahuan ibu, sebesar $45,6 \%$ ibu hamil tidak mengetahui akibat dari anemia, tidak teratur dalam mengkonsumsi tablet $\mathrm{Fe}$, dan tidak memahami cara mengkonsumsi tablet Fe secara tepat. Pengetahuan merupakan domain yang sangat penting dalam membentuk tindakan seseorang. Pengetahuan adalah salah satu faktor yang membentuk sikap seseorang. Pengetahuan yang baik tentang pentingnya zat besi akan membentuk sikap yang positif terhadap kepatuhan dalam mengkonsumsi tablet zat besi. Pengetahuan tentang manfaat sesuatu hal dapat mempengaruhi niat untuk ikut dalam suatu kegiatan, 


\section{Naili Rahmawati}

Pengetahuan akan segi manfaat dan akibat buruk sesuatu hal akan membentuk sikap, kemudian dari sikap itu akan muncul niat. Niat yang selanjutnya akan menentukan apakah kegiatan akan dilakukan atau tidak.

Tujuan: Mengetahui Hubungan antara Pengetahuan dengan Tindakan Ibu Hamil dalam mengkonsumsi Tablet Zat Besi di Praktik Mandiri Bidan 'l'.

Metode: Penelitian ini merupakan penelitian kuantitatif dengan pendekatan cross sectional. Data yang dikumpulkan menggunakan data primer. Penelitian dilakukan pada bulan Agustus - September 2019. Populasi dalam penelitian ini adalah ibu hamil di Praktik Mandiri Bidan I, Sampel dalam penelitian ini adalah sebagian dari ibu hamil di Praktik Mandiri Bidan I. Pengambilan sampel dilakukan dengan teknik accidental sumpling sebanyak 30 orang. Dengan kriteria inklusi bisa menulis, membaca, memahami bahasa indonesia dan dalam kondisi sehat. Peneliti menggunakan data primer, yaitu data yang diperoleh dengan wawancara dg instrument kuesioner. Analisis data yang digunakan dalam penelitian ini terdiri dari dua tahapan analisis sebagai berikut: analisis univariat Analisis univariat dan Analisis data penelitian dilakukan dengan menggunakan uji Spearman.

Hasil: Hasil penelitian diperoleh $97 \%$ ibu hamil memiliki pengetahuan baik, dan $3 \%$ ibu hamil dengan pengetahuan kurang, dan 100\% ibu hamil dengan tindakan positif dalam mengkonsumsi tablet besi. Analisis bivariat dengan uji spearman diketahui bahwa terdapat hubungan yang bermakna antara pengetahuan dengan tindakan ibu hamil dalam mengkonsumsi tablet zat besi. tablet besi.

Kesimpulan : Terdapat hubungan antara pengetahuan dengan tindakan ibu hamil dalam mengkonsumsi

Saran Untuk meningkatkan pengetahuan ibu hamil dalam mengkonsumsi tablet zat besi perlu dilakukan penyuluhan secara rutin oleh bidan dengan kerjasama dengan puskesmas.

Kata Kunci : pengetahuan, tindakan, ibu hamil, tablet besi

\section{PENDAHULUAN}

Anemia merupakan kondisi ibu dengan kadar hemoglobin $(\mathrm{Hb})$ dalam darahnya kurang dari $12 \mathrm{gr} \%$, sedangkan untuk ibu hamil adalah ketika kadar $\mathrm{Hb}$ dibawah $11 \mathrm{gr} \%$ pada trimester I dan III atau kadar $<10,5 \mathrm{gr} \%$ pada trimester II (Fatimah, Hadju et al, 2011). Anemia defisiensi zat besi merupakan penurunan jumlah sel darah merah yang disebabkan oleh zat besi yang terlalu sedikit. Besi adalah komponen utama dari hemoglobin. Kekurangan zat besi merupakan penyebab yang sangat umum dari anemia (Proverawati, 2011). Anemia sering terjadi akibat defisiensi zat besi karena pada ibu hamil terjadi peningkatan kebutuhan zat besi dua kali lipat akibat peningkatan volume darah tanpa ekspansi volume plasma, untuk memenuhi kebutuhan ibu (mencegah kehilangan darah pada saat melahirkan) dan pertumbuhan janin (Cunningham., 2001). Ironisnya, diestimasi dibawah $50 \%$ ibu tidak mempunyai cadangan zat besi yang cukup selama kehamilannya, sehingga risiko defisiensi zat besi atau anemia meningkat bersama dengan kehamilan.

Terdapat korelasi yang erat antara anemia pada saat kehamilan dengan kematian janin, abortus, cacat bawaan, berat bayi lahir rendah, cadangan zat besi yang berkurang pada anak atau anak lahir dalam keadaan anemia gizi. Kondisi ini menyebabkan angka kematian perinatal masih tinggi, demikian pula dengan mortalitas dan morbiditas pada ibu. Selain itu, dapat mengakibatkan perdarahan pada saat persalinan yang merupakan penyebab utama (28\%) kematian ibu hamil/bersalin di Indonesia (Ahmed F, Khan MR, Jackson AA , 2001). Menurut WHO (World Health Organization), di negara berkembang terdapat $40 \%$ kematian ibu berkaitan dengan anemia dalam kehamilan. Frekuensi ibu hamil di Indonesia yang mengalami anemia masih sangat tinggi yaitu 63,5\% dibandingkan di Amerika hanya $6 \%$. Angka kematian ibu hamil yang mengalami anemia pada triimester I kehamilan yaitu $20 \%$, trimester II sebesar $70 \%$, dan trimester III sebesar $70 \%$ (Cunningham., 2001). Pada trimester I kehamilan, zat besi yang dibutuhkan itu sedikit karena tidak terjadi menstruasi dan pertumbuhan janin masih lambat, kemudian pada trimester II dan trimester III kehamilan, volume darah dalam tubuh wanita hamil akan meningkat sampai $35 \%$, ini ekuivalen dengan $450 \mathrm{mg}$ zat besi untuk memproduksi sel-sel darah merah. Sel darah merah harus mengangkut oksigen lebih banyak untuk janin. Sedangkat saat melahirkan, perlu tambaham besi sekitar 300-350 mg akibat kehilangan darah. Sampai saat melahirkan, wanita hamil membutuhkan zat besi sekitar $40 \mathrm{mg}$ per hari atau dua kali lipat kebutuhan kondisi tidak hamil (Ojofeitimi, EO., et al 2008).

Pemberian suplemen besi setara $60 \mathrm{mg}$ elemen besi dan $0,25 \mathrm{mg}$ asam folat per hari selama 13 minggu dapat menurunkan angka anemia serta meningkatkan status besi ibu hamil, tetapi $1 / 3$ dari mereka masih menderita defisiensi 


\section{JKM (Jurnal Kebidanan Malahayati),Vol 7,No.2.April 2021, ISSN (Print) 2476-8944 ISSN (Online) 2579-762X, Hal 295-302}

besi dan 9\% masih anemia. Oleh karena itu, sangat penting memberikan asupan besi sejak masa prematernal supaya cadangan besi pada saat hamil cukup memadai (Sukrat B, Sirichotiyakul S., 2006). Pemberian suplement $\mathrm{Fe}$ untuk anemia berat dosisnya adalah 4-6 mg/kg BB/hari dalam dosis terbagi. Untuk anemia ringan -sedang : $3 \mathrm{mg} / \mathrm{kg}$ $\mathrm{BB} /$ hari dalam 3 dosis terbagi, selain itu yang penting juga adalah mengatur pola diet seimbang berdasarkan piramida makanan sehingga kebutuhan makronutrient dan mikronutrient dapat terpenuhi, meningkatkan konsumsi bahan makanan sumber besi terutama dari protein hewani seperti daging. Mengkonsumsi vitamin $C$ yang berasal dari buah - buahan bersama-sama dengan protein hewani, membatasi makanan yang dapat menghambat absorbsi besi misalnya polifenol atau pitat dan mengkonsumsi suplemen besi fero sebelum kehamilan direncanakan minimal 3 bulan sebelumnya apabila diketahui kadar feritin rendah (Ojofeitimi EO, et al., 2008; Fatimah, Hadju et al., 2011; Samhadi, 2007). Di Indonesia sebaiknya menu makanan terdiri atas nasi, daging/ayam/ikan, kacang-kacangan, serta sayuran dan buah-buahan yang kaya akan vitamin C (Ningrum, 2009)

Kebutuhan zat besi pada ibu hamil berbeda pada setiap umur kehamilannya, pada trimester I naik dari $0,8 \mathrm{mg} / \mathrm{hari}$, menjadi $6,3 \mathrm{mg} / \mathrm{hari}$ pada trimester III. Kebutuhan akan zat besi sangat menyolok kenaikannya. Dengan demikian kebutuhan zat besi pada trimester II dan III tidak dapat dipenuhi dari makanan saja, walaupun makanan yang dimakan cukup baik kualitasnya dan bioavailabilitas zat besi tinggi, namun zat besi juga harus disuplai dari sumber lain agar supaya cukup. (Hinderaker SG, et al, 2002; Departemen Kesehatan RI, 2001).

Zat besi adalah mikroelemen yang penting untuk tubuh. Zat ini terutama diperlukan dalam hemopoboesis (pembentukan darah) yaitu sintesis hemoglobin $(\mathrm{Hb})$. $\mathrm{Hb}$ yaitu suatu oksigen yang mengantarkan eritrosit berfungsi penting bagi tubuh. Hemoglobin terdiri dari Fe (zat besi), protoporfirin, dan globin (1/3 berat $\mathrm{Hb}$ terdiri dari Fe). (Departemen Kesehatan R.I., 2001). Besi memiliki beberapa fungsi esensial di dalam tubuh yaitu untuk alat angkut oksigen dari paru-paru ke jaringan tubuh, sebagai alat angkut elektron di dalam sel, dan sebagai bagian terpadu berbagai reaksi enzim di dalam jaringan tubuh. (Linda, J. Harvey, et al., 2007)

Patofisiologi defisiensi besi pada ibu hamil terjadi karena darah akan bertambah banyak dalam kehamilan yaitu disebut Hidremia / Hipervolemia. Namun, bertambahnya sel darah kurang dibandingkan dengan bertambahnya plasma sehingga terjadi pengenceran darah. Perbandingan tersebut terdiri dari plasama 30\%, sel darah $18 \%$ dan haemoglobin 19\%. Bertambhanya darah dalam kehamilan sudah dimulai sejak kehamilan 10 minggu dan mencapai puncaknya dalam usia kehamilan 32 dam 36 minggu. Pengenceran darah secara fisiologis ini untuk membantu meringankan kerja jantung yang semakin berat karena kehamilan (Winkjosastro, H., 2002).

Beberapa hal yang dapat menyebabkan defisiensi zat besi adalah kebutuhan meningkat seperti pada ibu hamil, malabsorbsi dan diet yang buruk, kehilangan darah, misalnya dari uterus atau gastrointestinal seperti ulkus peptikum, karsinoma lambungm dIl, kurangnya kandungan zat besi dalam makanan sehari-hari, penyerapan zat besi dari makanan yang sangat rendah, adanya zat-zat yang menghambat penyerapan zat besi, dan adanya parasit di dalam tubuh seperti cacing tambang atau cacing pita, diare, atau kehilangan banyak darah akibat kecelakaan atau operasi (Purba, T.R., 2007)

Banyaknya ibu hamil yang mengalami anemia disebabkan karena kurangnya pengetahuan ibu, sebesar $45,6 \%$ ibu hamil tidak mengetahui akibat dari anemia, tidak teratur dalam mengkonsumsi tablet $\mathrm{Fe}$, dan tidak memahami cara mengkonsumsi tablet $\mathrm{Fe}$ secara tepat. Pengetahuan merupakan domain yang sangat penting dalam membentuk tindakan seseorang. Pengetahuan merupakan hasil dari tahu, dan ini terjadi setelah melakukan penginderaan terhadap suatu objek tertentu. Pengetahuan merupakan faktor yang sangat penting untuk terbentuknya tindakan seseorang. Pengetahuan yang didasari pemahaman yang tepat akan menimbulkan pemahaman yang positif sehingga akhirnya tumbuh satu bentuk perilaku yang diharapkan (Notoatmodjo, 2012).

Pengetahuan merupakan salah satu faktor penting untuk membentuk suatu sikap yang utuh. Semakin baik pengetahuan seseorang semakin baik sikap yang akan terbentuk untuk menciptakan suatu tindakan yang baik pula. Ibu hamil dengan pengetahuan yang baik mengenai pentingnya zat besi dan akibat yang ditimbulkan apabila kekurangan zat besi dalam kehamilan akan cenderung membentuk sikap yang positif terhadap kepatuhan sehingga timbul tindakan patuh dalam mengkonsumsi tablet besi (Sunaryo, 2004).

Tindakan adalah upaya untuk mewujudkan sikap menjadi suatu perbuatan nyata yang memerlukan faktor pendukung atau kondisi yang memungkinkan (Effendi, 2009). Menurut Green (1980), perilaku dipengaruhi oleh 3 faktor utama 
yaitu : Faktor Predisposisi yang mencakup pengetahuan dan sikap masyarakat terhadap kesehatan, kemudian faktor pendukung ini mencakup ketersediaan sarana dan prasarana atau fasilitas kesehatan bagi masyarakat dan terakhir adalah faktor pendorong yang mencakup sikap dan perilaku petugas kesehatan, atau petugas yang lain, yang merupakan kelompok referensi dari perilaku masyarakat.

Berdasarkan penelitian sebelumnya menunjukkan terdapat hubungan antara pengetahuan dengan sikap ibu hamil dalam mengkonsumsi tablet zat besi di PBM Bidan I Kabupaten Bandung, Tahun 2019 oleh karena itu peneliti tertarik untuk melakukan penelitian selajutnya tentang hubungan antara pengetahuan dengan tindakan ibu hamil dalam mengkonsumsi tablet zat besi di PBM Bidan I Kabupaten Bandung, Tahun 2019.

\section{METODOLOGI PENELITIAN}

Penelitian ini menggunakan desain observasional dengan pengambilan data pada waktu sesaat dan secara bersamaan (cross sectional). Penelitian ini merupakan penelitian kuantitatif menggunakan data primer untuk mengetahui hubungan pengetahuan dengan tindakan ibu hamil dalam mengkonsumsi tablet zat besi di Praktik Mandiri Bidan I , Penelitian dilakukan pada bulan Agustus - September 2019. Populasi dalam penelitian ini adalah ibu hamil di Praktik Mandiri Bidan I, Sampel dalam penelitian ini adalah sebagian dari ibu hamil di Praktik Mandiri Bidan I. Pengambilan sampel dilakukan dengan teknik accidental sumpling sebanyak 30 orang. Dengan kriteria inklusi bisa menulis, membaca, memahami bahasa indonesia dan dalam kondisi sehat.

Pengukuran variabel pengetahuan tentang konsumsi tablet zat besi menggunakan kuesioner dari penelitian terdahulu berupa pertanyaan sebanyak 10 butir soal, yang sebelumnya telah dilakukan uji validitas dan realiabilitas instrumen. Hasil uji validitas dengan menggunakan jumlah responden 30 maka nilai $r$ tabel dapat diperoleh melaui tabel $r$ product moment pearson nilai $r>r$ tabel $(0,374)$ uji realibilitasnya yaitu $r=0,906$. Pengukuran variabel tindakan ibu hamil dalam mengkonsumsi tablet zat besi menggunakan kuesioner dari penelitian terdahulu berupa pertanyaan sebanyak 6 butir soal, yang sebelumnya telah dilakukan uji validitas dan realiabilitas instrumen. Hasil uji validitas dengan menggunakan jumlah responden 30 maka nilai $r$ tabel dapat diperoleh melaui tabel $r$ product moment pearson nilai $r>r$ tabel $(0,374)$ uji realibilitasnya yaitu $r=$
0,906. . Data diperoleh dengan tehnik wawancara. Variabel independen dalam penelitian ini adalah pengetahuan ibu hamil dalam mengkonsumsi zat besi dengan di bagi 2 kategori yaitu kategori baik dan kurang dan variabel dependen dalam penelitian ini adalah tindakan ibu hamil dalam mengkonsumsi zat besi dengan hasil ukur skor benar $\geq 60 \%$ dari pernyataan tindakan $=$ baik dan skor benar $<60 \%$ dari penyataan tindakan $=$ kurang baik. Untuk variabel Pengetahuan dan tindakan instrumen pengumpulan data dilakukan dengan menggunakan instrumen berbentuk skala, yakni sebuah pengumpul data yang berbentuk seperti daftar cocok dengan alternative jawaban yang disediakan. Peneliti menggunakan data primer, yaitu data yang diperoleh dengan wawancara $\mathrm{dg}$ instrument kuesioner.

Analisis data yang digunakan dalam penelitian ini terdiri dari dua tahapan analisis sebagai berikut: analisis univariat Analisis univariat atau deskriptif yaitu analisis yang bertujuan untuk mendapatkan gambaran distribusi frekuensi dan proporsi dari masing-masing variabel yang diteliti sehingga diperoleh hasil analisis untuk masingmasing variabel yang diteliti dalam bentuk tabel univariat (Notoatmodjo, 2010) . Analisis data penelitian dilakukan dengan menggunakan uji Spearman, yaitu uji korelasi untuk dua variabel dengan skala nominal atau ordinal

\section{HASIL DAN PEMBAHASAN}

Analisis univariat

Tabel 1

Distribusi Pengetahuan ibu hamil dalam mengkonsumsi tablet zat besi

\begin{tabular}{lcc}
\hline Kategori pengetahuan & $\mathbf{N}$ & $\%$ \\
\hline Baik & 29 & 97 \\
Kurang & 1 & 3 \\
\hline Total & 30 & 100 \\
\hline
\end{tabular}

Sumber : data primer 2019

Berdasarkan tabel 1 menunjukkan bahwa sebagian besar ibu hamil memiliki pengetahuan baik sebesar $97 \%$, dan $3 \%$ ibu hamil dengan pengetahuan kurang.

Tabel 2.

Distribusi tindakan ibu hamil dalam mengkonsumsi tablet zat besi

\begin{tabular}{lcc}
\hline \multicolumn{1}{c}{ Kategori tindakan } & N & $\%$ \\
\hline Baik & 30 & 100 \\
Kurang & 0 & 0 \\
\hline
\end{tabular}




\begin{tabular}{ccc}
\hline Total & 30 & 100 \\
\hline Sumber : data primer 2019 &
\end{tabular}

Berdasarkan Tabel 2 menunjukkan bahwa semua ibu hamil memiliki tindakan baik (100\%).

Analisis Bivariat
Hasil analisis dengan uji spearman diperoleh nilai $\rho=0,000$ yang menunjukkan terdapat hubungan yang bermakna antara pengetahuan dengan tindakan ibu hamil dalam mengkonsumsi tablet zat besi.

Tabel 3

Hubungan antara pengetahuan dengan tindakan ibu hamil dalam mengkonsumsi tablet zat besi di Praktik Mandiri Bidan 'l' Kabupaten Bandung pada bulan agustus sampai september 2019

\begin{tabular}{|c|c|c|c|c|c|c|c|}
\hline \multirow{3}{*}{ Kategori pengetahuan } & \multicolumn{4}{|c|}{ Tindakan } & \multirow{2}{*}{\multicolumn{2}{|c|}{ Total }} & \multirow{3}{*}{ Nilai $\rho$} \\
\hline & \multicolumn{2}{|c|}{ Baik } & \multicolumn{2}{|c|}{ Kurang Baik } & & & \\
\hline & $\mathbf{N}$ & $\%$ & $\mathbf{N}$ & $\%$ & $\mathbf{N}$ & $\%$ & \\
\hline Baik & 29 & 97 & 0 & 0 & 29 & 97 & \multirow{2}{*}{0,000} \\
\hline Kurang & 1 & 3 & 0 & 0 & 1 & 3 & \\
\hline Jumlah & 30 & 100 & 0 & 0 & 30 & 100 & \\
\hline
\end{tabular}

\section{PEMBAHASAN}

Pengetahuan ibu hamil dalam mengkonsumsi tablet zat besi di Praktik Mandiri Bidan 'I' Kabupaten Bandung pada bulan agustus sampai september 2019.

Berdasarkan tabel 1 menunjukkan bahwa sebagian besar ibu hamil memiliki pengetahuan baik sebesar $97 \%$ dan $3 \%$ ibu hamil dengan pengetahuan kurang. Hal ini berbeda dengan penelitian yang dilakukan oleh Ana Wigunantiningsih (2011) yang menunjukkan bahwa tingkat pengetahuan ibu hamil tentang tablet $\mathrm{Fe}$ secara umum termasuk dalam kategori cukup sejumlah 29 responden (53.7\%). Hal ini berbeda dengan penelitian Al Hadar, Safirah Azzahara (2014) yang menunjukkan bahwa ibu hamil memiliki pengetahuan kurang mengenai pentingnya mengkonsumsi tablet zat besi selama kehamilanya karena rendahnya tingkat pendidikan dan pekerjaan ibu hamil yang mayoritas ibu rumah tangga dan pada penelitian ini hanya menggunakan dua kategori baik dan kurang. Pengetahuan adalah informasi atau maklumat yang diketahui atau disadari oleh seseorang (Budiman, 2013).

Pengetahuan tentang pengertian tablet zat besi, fungsi zat besi, waktu yang dianjurkan dalam mengkonsumsi zat besi dan informasi lainya dapt diperoleh ibu hamil melalui penyuluhan yang diberikan bidan dalam kunjungan ANC. Setiap kunjungan di Praktik Mandiri Bidan "I" ibu hamil selalu mendapatkan penyuluhan tentang tablet zat besi dan selalu diberi tablet zat besi. Pengetahuan yang baik ini dapat disebabkan oleh berbagai faktor termasuk faktor pengalaman dan pendidikan (Notoadmodjo, 2010). Pengetahuan tidak hanya didapatkan dari pendidikan formal. Pengetahuan dapat diperoleh dari lingkungan pergaulan, informasi media massa, dukungan keluarga atau suami maupun dari penyuluhan tenaga kesehatan. Penyuluhan dan motivasi dari petugas kesehatan merupakan faktor lain yang dapat mempengaruhi pengetahuan. Penyuluhan dan motivasi berguna saat pasien menghadapi bahwa perilaku sehat merupakan hal penting. Jika petugas kesehatan memberikan motivasi untuk mengkonsumsi tablet zat besi pada ibu hamil maka konsumsi tablet zat besi akan lebih mudah tercapai (Utami WT, Apriastuti DA, 2013).

Sebagian besar ibu hamil patuh mengkonsumsi tablet $\mathrm{Fe}$, dapat dipengaruhi oleh pengetahuan ibu hamil yang baik. Pengetahuan akan menghasilkan kesadaran bagi ibu hamil untuk mengkonsumsi tablet $\mathrm{Fe}$ secara teratur selama kehamilanya. (Astuti D, Kudus SM, 2016).

Pengetahuan merupakan hasil dari tahu dan terjadi setelah orang melakukan pengindreraan terhadap suatu objek tertentu melalui pancaindera yaitu indera penglihatan, penciuman, pendengaran, rasa dan raba. Sebagian besar pengetahuan manusia diperoleh melalui mata dan telinga (Notoadmodjo, 2012).

Tindakan ibu hamil dalam mengkonsumsi tablet zat besi di Praktik Mandiri Bidan 'l' Kabupaten Bandung pada bulan agustus sampai september 2019

Berdasarkan Tabel 2 menunjukkan bahwa semua ibu hamil memiliki tindakan baik (100\%). Hal ini berbeda dengan penelitian. Al Hadar, Safirah Azzahara (2014) yang menunjukkan bahwa dari 45 responden $(49 \%)$ memiliki tindakan yang baik dan 23 responden (51\%) memiliki tindakan yang kurang 
baik, dan menurut Zulhadi (2009) umumnya tindakan ibu hamil dalam mengkonsumsi tablet zat besi di puskesmas Aleu le Mirah Kecamatan Indra Makmu Kabupaten Aceh Timur adalah baik sebesar 36 orang $(52,9 \%)$.

Tindakan adalah upaya untuk mewujudkan sikap menjadi suatu perbuatan nyata yang memerlukan faktor pendukung atau kondisi yang memungkinkan (Effendi, 2009). Tingkatan tindakan : 1). Persepsi (perception). Mengenal dan memilih berbagai objek sehubungan dengan tindakan yang akan diambil merupakan praktik tingkat pertama. Contohnya, seorang Ibu dapat memilih makanan yang bergizi tinggi bagi anak balitanya. 2). Respons terpimpin (guide response). Dapat melakukan sesuatu sesuai dengan urutan yang benar dan sesuai dengam contoh merupakan indikator praktik tingkatan kedua. 3). Mekanisme (mechanism). Apabila seseorang telah dapat melakukan sesuatu dengan benar secara otomatis, atau sesuatu itu sudah merupakan kebiasaan, maka ia sudah mencapai praktik tingkat ketiga. 4). Adopsi (adoption). Adaptasi merupakan suatu praktik atau tindakan yang sudah berkembang dengan baik. Artinya tindakan itu sudah dimodifikasikannya tanpa mengurangi kebenaran tindakan tersebut (Effendi, 2009).

Faktor - Faktor yang Mempengaruhi Tindakan : Menurut Green (1980) dalam effendi (2009), perilaku dipengaruhi oleh 3 faktor utama yaitu : 1. Faktor Predisposisi (Predisposing Factor). Faktor predisposisi mencakup pengetahuan dan sikap masyarakat terhadap kesehatan. 2. Faktor Pendukung (Enabling Factors) Faktor-faktor ini mencakup ketersediaan sarana dan prasarana atau fasilitas kesehatan bagi masyarakat. 3. Faktor Pendorong (Renforcing Factor) Faktor pendorong mencakup sikap dan perilaku petugas kesehatan, atau petugas yang lain, yang merupakan kelompok referensi dari perilaku masyarakat.

\section{Hubungan antara pengetahuan dengan tindakan ibu hamil dalam mengkonsumsi tablet zat besi di Praktik Mandiri Bidan 'l' Kabupaten Bandung pada bulan agustus sampai september 2019}

Hasil analisis dengan uji spearman diperoleh nilai $\rho=0,000$ yang menunjukkan terdapat hubungan yang bermakna antara pengetahuan dengan tindakan ibu hamil dalam mengkonsumsi tablet zat besi.

Hasil penelitian ini menunjukkan bahwa pengetahuan yang dimiliki oleh ibu hamil dalam mengkonsumsi tablet zat besi akan mempengaruhi tindakan ibu hamil dalam mengkonsumsi tablet zat besi. Hal ini sejalan sesuai dengan teori Green
(1980) dalam Effendi (2009), ada beberapa faktor yang mempengaruhi tindakan yaitu pengetahuan dan sikap maysarakat. Dengan adanya pengetahuan yang baik disertai sikap yang baik pula, maka akan memberikan pengaruh untuk melakukan tindakan yang baik pula. Berdasarkan penelitian Sri (2006) bahwa ibu hamil di Bantul yang memiliki pengetahuan mengenai anemia yang cukup belum dapat mendorong ibu hamil untuk lebih patuh mengonsumsi tablet zat besi akan tetapi terdapat kecenderungan bahwa sebagian besar ibu hamil yang patuh memiliki pengetahuan yang baik. Selanjutnya terdapat hubungan yang signifikan antara pengetahuan ibu hamil dengan kepatuhan konsumsi tablet Fe $(p$ value $=0.001$ ) (Vongvichit Phasouk, 2003)

Pengetahuan yang baik tentang pentingnya zat besi akan membentuk sikap yang positif terhadap kepatuhan dalam mengkonsumsi tablet zat besi (Sunaryo, 2004). Pengetahuan merupakan faktor yang berhubungan dengan sikap ibu hamil dalam mengkonsumsi tablet zat besi (Rahmawati, 2020). Pengetahuan tentang manfaat sesuatu hal dapat mempengaruhi niat untuk ikut dalam suatu kegiatan. Pengetahuan akan segi manfaat dan akibat buruk sesuatu hal akan membentuk sikap, kemudian dari sikap itu menentukan apakah kegiatan akan dilakukan atau tidak (Marliana, 2018).

\section{SIMPULAN}

Sebagian besar ibu hamil memiliki pengetahuan baik sebesar $97 \%$ dan semua ibu hamil memiliki tindakan baik 100\%. Dan terdapat hubungan yang bermakna antara pengetahuan dengan tindakan ibu hamil dalam mengkonsumsi tablet zat besi.

\section{SARAN}

Untuk meningkatkan pengetahuan ibu hamil tentang tablet zat besi perlu adanya penyuluhan yang dilakukan oleh Bidan dengan kerjasama dengan puskesmas.

\section{DAFTAR PUSTAKA}

Ahmed F, Khan MR, Jackson AA. (2001). Concomitant Supplemental Vitamin A Enhances the Response to Weekly Supplemental Iron and Folic Acid in Anemic Teenagers In Urban Bangladesh. Am. J. Clin. Nutr. 2001; 74(1):108-115. 


\section{JKM (Jurnal Kebidanan Malahayati),Vol 7,No.2.April 2021, \\ ISSN (Print) 2476-8944 ISSN (Online) 2579-762X, Hal 295-302}

Al Hadar, Safirah Azzahara. (2014). Gambaran pengetahuan, sikap dan tindakan ibu hamil terhadap pentingnya mengkonsumsi tablet zat besi selama kehamilannya di puskesmas layang makassar tahun 2014. Diunduh dari: http://repositori.uin-alauddin.ac.id/6490 tanggal 19 agustus 2020

Astuti D, Kudus SM. (2016) Faktor Yang Berhubungan Dengan Kejadian Anemia Pada Ibu Hamil di Puskesmas Undaan Lor Kabupaten Kudus. In: The 3rd University Research Colloquium 2016. Diunduh dari: https://publikasiilmiah.ums.ac.id/handle/1161 7/6723 tanggal 05 April 2021.

Budiman, Agus Riyanto.(2013). Kapita Selekta Kuesioner Pengetahuan dan Sikap dalam Penelitian Kesehatan. Jakarta: Salemba Medika.

Cunningham dan Garry F. (2001). Obstetri Williams Edisi 21 Vol 2 [Hartono et al., trans]. Jakarta: Penerbit Buku Kedokteran EGC.

Dahlan MS. (2011). Statistik untuk Kedokteran dan Kesehatan, Seri Evidence Based Medicine Edisi 1. Jakarta: Salemba

Departemen Kesehatan R.I. (2001). Program Penanggulangan Anemia Gizi pada Wanita Usia Subur (WUS); (Safe Motherhood Project: A Partnership and Family Approach). Direktorat Gizi Masyarakat. Jakarta: Direktorat Jenderal Bina Kesehatan Masyarakat Depkes, 2001.

Effendi, Ferry. (2009). Keperawatan Kesehatan Komunitas: Teori dan Praktik Dalam Keperawatan. Jakarta: Salemba Medika.

Fatimah, Hadju et al. (2011). Pola Konsumsi dan Kadar Hemoglobin Pada Ibu Hamil Di Kabupaten Maros,Sulawesi Selatan. Makara,Kesehatan. 2011; 15(1): 31-36

Hinderaker SG, Olsen BE, Lie RT, et al. (2002). Anemia in pregnancy in rural Tanzania: associations with micronutrients status and infections. Eur. J. Clin. Nutr. 2002; 56(3):192-199

Linda J Harvey, Jack R Dainty, Wendy J Hollands, et al. (2007). Effect of high-dose iron supplements on fractional zinc absorption and status in pregnant women. American Journal of Clinical Nutrition, 2007; 85 (1): $131-136$

Marliana Rahma. (2018). Hubungan antara pengetahuan seksualitas dengan perilaku seksual remaja di SMA Negeri 1 Subang, Jurnal Bidan "Midwife Journal" Volume 5 No. 01

Ningrum. Pemberian Tablet Fe Pada Ibu Hamil Untuk Mencegah Anemia. 2009. Diunduh dari

Http://Ningrumwahyuni.Wordpress.Com/200 9/09/04/PemberianTablet-Fe-Pada-IbuHamil-Untuk-Mencegah-Anemia tanggal 28 april 2021.

Notoadmodjo. (2010). Metodologi Penelitian kesehatan. Jakarta: PT. Rineka Cipta.

Notoatmodjo. (2012). Pendidikan dan Perilaku Kesehatan. Edisi Revisi. Jakarta: Rineka Cipta.

Ojofeitimi EO, Ogunjuyigbe PO, Sanusi, et al. (2008). Poor Dietary Intake of Energy and Retinol among Pregnant Women: Implications for Pregnancy Outcome in Southwest Nigeria. Pak. J. Nutr. 2008; 7(3):480-484

Proverawati, Atikah. (2011). Anemia dan Anemia Kehamilan. Yogyakarta: Nuha Media.

Rahmawati, Naili. (2020). Hubungan antara Pengetahuan dengan Sikap Ibu Hamil dalam Mengkonsumsi Tablet Zat Besi di Praktik Bidan 'l' Kabupaten Bandung Tahun 2019. Proceeding Publikasi IImiah Nasional Oral Presentasi dalam Rangka HUT IBI Ke-69.

Regina Tatiana Purba. Departemen Obstetri dan Ginekologi, Fakultas Kedokteran Universitas Indonesia .(2007). erbandingan Efektivitas Terapi Besi Intravena dan Oral pada Anemia Defisiensi Besi dalam Kehamilan. Maj Kedokt Indon. 2007; 57 (4), April. Rumah Sakit Dr. Cipto Mangunkusumo, Jakarta

Saifuddin, AB. (2002). Pelayanan Kesehatan Maternal dan Neonatal. Jakarta: Yayasan Bina Pustaka Sarwono Prawirohardjo. 
Samhadi. Malnutrisi, Keteledoran Sebuah Bangsa. 2008. Diunduh dari: www.kompas.com tanggal 28 april 2021.

Sri Purwaningsih, Marlia, Akhmadi. (2006). Analisis Faktor Yang Mempengaruhi Ketidakpatuhan Ibu Hamil dalam Mengonsumsi Tablet Fe. Diunduh dari: https://jurnal.ugm.ac.id/jik/article/view/10125 tanggal 05 April 2021

Sugiyono. (2011) Metode penelitian kuantitatif kualitatif dan R\&D. Bandung: Alfabeta

Sukrat B. and Sirichotiyakul S. (2006). The prevalence and causes of anemia during pregnancy in Maharaj Nakorn Chiang Mai Hospital. J. Med. Assoc. Thai 2006; 89(Suppl 4):S142-146

Sunaryo. ( 2004). Psikologi untuk keperawatan. Jakarta: EGC.

Utami WT, Apriastuti DA. (2013) Gambaran Pengetahuan Ibu Hamil Tentang Manfaat Tablet Fe Di Desa Candi, Kecamatan Ampel, Kabupaten Boyolali. J Kebidanan. Diunduh dari

http://journal.stikeseub.ac.id/index.php/jk eb/article/view/107/0 tanggal 5 April 2021
Vongvichit, Phasouk. (2003). Compliance of Pregnant Women Regarding Iron Supplementation in Vientiane Municipality, Lao P.D.R. Journal of Public Health and Development, Vol. 11 No.1.

Wantonoro PS. (2015). Hubungan Cara Konsumsi Tablet Fe dengan Kejadian Anemia pada Ibu Hamil Trimester II dan III di Puskesmas Tegalrejo Yogyakarta. Stikes Aisyiyah Yogyakarta.

http://digilib.unisayogya.ac.id/751/ (diakses 04 April 2021).

Wigunantiningsih, Ana. (2011). Tingkat pengetahuan ibu hamil tentang tablet $\mathrm{Fe}$ di BPS Sulastri Wonolopo Tasikmadu Karanganyar vol. 4. Diunduh dari http://ejurnal.mithus.ac.id/index.php/maternal larticle/download/142/127 tanggal 19 Oktober 2020

Winkjosastro Hanifa.(2002) IImu Kebidanan. Jakarta: EGC

Zulfadli. (2009). Perilaku ibu hamil dalam mengkonsumsi Tablet Zat Besi (Fe) di Puskesmas Alue le Mirah Kecamatan Indra Makmu Kabupaten Aceh Timur tahun 2009 Diunduh

dari http://repository.usu.ac.id/handle/123456789/ 25261 tanggal 05 april 2021 